\title{
Intravenous infusion of a dextrin, Caloreen, in human subjects: metabolic studies
}

\author{
By R. J. BIBBY, D. DAVIES AND N. P. MALLICK \\ Departments of Endocrinology and Nephrology, \\ Manchester Royal Infirmary, Manchester 13 \\ AND S. T. ATHERTON AND D. M. WRIGHT \\ Clinical Research Laboratory, Whiston Hospital, Liverpool \\ AND C. R. RICKETTS* \\ $M R C$ Industrial Injuries and Burns Unit, \\ Birmingham Accident Hospital, Birmingham 15 \\ AND J. MILNER \\ Milner Scientific and Medical Research Co., Ltd, Liverpool
}

(Received 19 July 1976 - Accepted 10 March 1977)

1. Caloreen, a glucose-polymer dextrin infused into human volunteers, although producing a clear increase in total plasma carbohydrate did not produce a satisfactory increase in plasma glucose levels or serum insulin levels.

2. Urinary losses were high and although small fragments of the dextrin (suggesting metabolic breakdown of the dextrin) were demonstrated in the urine, no suppression of plasma free fatty acid, glucagon or immediate increase in the respiratory quotient were noted, suggesting that the metabolism is too slow to make it useful for parenteral nutrition in its present form.

3. A dextrin with fewer branch-links might be more suitable.

In parenteral nutrition there is a need to put into the bloodstream those substances which normal nutrition puts there and, ideally, to do this in their usual proportions. To some extent this can now be done with amino acids and fat emulsions, but for glucose concentrated solutions must be used to avoid giving too much water; these solutions are strongly hypertonic and give some trouble with thrombo phlebitis (Peaston, 1968). A possible way out of this difficulty is to use oligo- or polysaccharides which can be more nearly isotonic at higher concentrations. Starch or dextrin seems an obvious choice, since enzymes for their hydrolysis to maltose and ultimately to glucose are widely present in the body. A practical upper limit to molecular weight is the viscosity of starch solution; the lower limit is set by the hypertonicity of concentrated solutions.

The dextrin, Caloreen, has been widely used to provide a palatable high-energy source in the dietary management of patients with renal and hepatic failure. It has previously been shown (Mallick, Davies \& Dobbs, 1972) that the response of insulin and blood glucose to oral administration of Caloreen is identical with the response to an equal weight of glucose, and it has also been shown (Berlyne, Booth, Brewis \& Mallick, 1969) that in the fasting state the respiratory quotient (RQ) increases towards a value of 1.0 after oral administration of Caloreen, as would be expected if it was being satisfactorily metabolized.

The current study was undertaken to investigate the metabolism of Caloreen when infused intravenously in man; a preliminary account of this work has already been published (Bibby, Davies, Mallick, Atherton, Wright, Sherwood-Jones, Ricketts \& Hall, 1974).

* To whom requests for reprints should be addressed. 


\section{MATERIALS AND METHODS}

The dextrin, Caloreen, consists of glucose units linked by 1,4- $\alpha$-glucosidic bonds with about $25 \%$ of 1,6 linkages remaining from the original starch. A wide distribution of molecular weight was present ranging from glucose to molecules containing more than thirty glucose units; the average was between five and six glucose units. An isotonic solution of Caloreen contained $225 \mathrm{~g} / \mathrm{l}$ water. In this work a sterile, pyrogen-free, slightly hypertonic solution ( $300 \mathrm{~g}$ Caloreen/l) containing $5 \mathrm{MJ} / \mathrm{l}$ (Milner Scientific and Medical Research Ltd, Liverpool) was used.

Subjects, who were all normal medical student volunteers age 21-23 years, were given $25 \mathrm{~g}$ Caloreen by intravenous injection into one arm in a period of 1-2 min, and blood samples removed from the other arm by means in an indwelling cannula kept open by lightly-heparinized saline ( $9 \mathrm{~g}$ sodium chloride/l, 1-2 heparin units per $\mathrm{ml}$ ). The first $2 \mathrm{ml}$ blood removed was discharged as this was contaminated by heparin and saline. Samples were taken 60 and $30 \mathrm{~min}$ before the injection and at $0,2,5,10,20,30,40,60,90,120$ and $150 \mathrm{~min}$ after the injection. Samples were analysed for total carbohydrate by the anthrone method of Roe (1954), and for amylase (EC 3.2.1.1 and 3.2.1.2) using the Phadebas kit (Pharmacia, Uppsala, Sweden) which uses the release of a blue dye from an insoluble starch preparation as a measure of amylase activity. Insulin (Hales \& Randle, 1963) and growth hormone (Hunter \& Greenwood, 1964) were determined by radioimmunoassay. Urea and glucose were determined using a 'Technicon' autoanalyser. Lower values for glucose were found using the alkaline copper-reduction method of Assatoor \& King, as quoted by Varley (1969). At the start of each study, $10 \mu \mathrm{Ci}{ }^{51} \mathrm{Cr}$-EDTA was administered intravenously $60 \mathrm{~min}$ before injection of Caloreen and blood samples were taken frequently during the first hour to establish the clearance of EDTA and to allow estimation of glomerular filtration rate (GFR).

Urine samples were collected at 30 min intervals. After the first two studies, a water-load of 11 was given at the beginning of the study, and additional water, equivalent to the urine volume, was given at 30 min intervals. The volumes of urine samples were measured and portions used to estimate total carbohydrate content using the anthrone reagent (Roe, 1954). The sugars and dextrins present were examined by paper chromatography on Whatman No. 1 paper using butanol-ethanol-water $(50: 30: 20$, by vol.) as the developing solvent; a silver nitrate reagent was used to detect the presence of carbohydrate. Dextrins of higher molecular weight were examined by gel filtration on columns of Sephadex G-25 or G-200 (Pharmacia); effluent from the columns was monitored by automatic recording of refractive index, proportional to dextrin concentration.

For the determination of RQ, subjects wore a nose-clip and breathed through a nonrebreathing valve so that expired air could be collected into a Douglas bag. After the subject was accustomed to this procedure, expired air was used to wash out the collection tubing and the Douglas bag; the latter was then emptied and a 'timed' sample of expired air was collected for $3 \mathrm{~min}$. The volume of expired air collected was measured using a gas meter (Parkinson-Cowan) and allowance was made for the volume of expired air used to determine the oxygen and carbon monoxide concentrations. Duplicate analyses of $\mathrm{O}_{2}$ content of the expired air were made using an $\mathrm{O}_{2}$ analyser (Lex- $\mathrm{O}_{2}$-Con; Lexington), (Clerbaux, Gerets \& Franz, 1973) and for $\mathrm{CO}_{2}$ a modified Haldane apparatus (Campbell, 1960 ) was used; the accuracy of gas analysis using this procedure has already been validated (Tang, R. \& Stretton, $\mathrm{T}$, unpublished results). $\mathrm{O}_{2}$ consumption and $\mathrm{CO}_{2}$ output were calculated and the respiratory exchange ratio, $\mathrm{O}_{2}$ consumption: $\mathrm{CO}_{2}$ output, was derived. Under the conditions of these experiments, in which subjects were at rest throughout and there was no significant change in 'minute' ventilation volume, changes in $R$ were assumed to reflect changes in the $R Q$. 


\section{ETHICAL CONSIDERATION}

The Ethical Committee at Manchester Royal Infirmary approved the project before the inception of the study. Due consideration was given to the fact that large quantities of Caloreen have been given orally in treatment of patients with severe liver disease and renal disease; that careful animal studies had proved it to be non-toxic; that the solutions contained no pyrogenic materials; and that the molecular size of the material used was less than that of dextran 40 B.P., frequently used for intravenous infusion, thus allowing the dextrin to be excreted unchanged in the urine if metabolic breakdown of the infused material did not occur. Solutions were carefully chosen at a concentration which was near to isotonic, and as a result, no problems of venous irritation occurred even in the prolonged infusion studies. Further, the study was not considered to be purely academic, for the benefits which would accrue if this were found to be a feasible way of providing high-energy-lowvolume nutrition to the seriously-ill patient, would be great. It was in this light that the study was undertaken.

The volunteer subjects at Whiston Hospital, where some of the larger continuous infusions took place were all medically qualified, except one who was a Nursing Sister.

\section{RESULTS}

Four subjects were given $25 \mathrm{~g}$ Caloreen as a single bolus injection intravenously. Results are shown in Tables 1 and 2. Two subjects (A and B) were male and two (C and D) were female, and all were 22 to 23 years of age. In all subjects the increase and decrease in total carbohydrate in the blood after injection was reflected in the increase and decrease in blood glucose as measured by the glucose-oxidase method. It was found that if a solution of Caloreen were subjected to analysis by the glucose-oxidase method, approximately $50 \%$ was estimated as glucose. A solution containing $2000 \mathrm{mg}$ Caloreen/l gave a value of $1000 \mathrm{mg} / \mathrm{l}$ with the glucose-oxidase method, but only $200 \mathrm{mg} / \mathrm{l}$ by the $\mathrm{Cu}$-reducing method.

The composition of the mixture of glucose and maltose and short-chain dextrins present in the circulation was continually changing through the action of plasma amylase, cellular metabolism and renal excretion. No simple method of analysing this mixture was available. Consequently the part played by intermediate molecules could not be assessed in this study.

A striking feature of all the studies is that despite the increase in blood glucose there was no response of immuno-reactive insulin, although the immuno-reactive growth hormone showed some suppression as the glucose increased. Levels of amylase in the serum appear to decrease progressively after the injection, in the two subjects in which this was estimated. In the first study, the blood urea was also estimated at intervals, but did not change throughout the study.

In all subjects the GFR, as measured by Cr-EDTA, tended to decrease in the first hour of the study, but remained constant thereafter (Table 2). It was considered that the early results were not reliable, as approximately $90-120 \mathrm{~min}$ were required for a steady-state to be reached, and the Cr-EDTA was actually given only $1 \mathrm{~h}$ before the study began, allowing inadequate time for equilibration. However, it was possible to demonstrate that Caloreen did not induce an osmotic diuresis, such as may be seen after infusions of mono- or disaccharide, an important factor if the agent is of potential use in parenteral nutrition.

In early studies, the subjects were not given fluid for $12 \mathrm{~h}$ before the study, and throughout the duration of the study. It was felt that this would lead to less than maximal urinary losses of Caloreen, which may have led to under-estimation of losses occurring under conditions of normal hydration. In order to maximize urinary losses of Caloreen, at the start of each study a water-load of 11 was given orally to each subject, and urinary losses were replaced by an equivalent volume of water given orally each hour. After Caloreen 
Table 1. Results of the analysis of blood* from four normal healthy subjects given $25 \mathrm{~g}$ Caloreen by rapid intravenous injection as a solution containing $300 \mathrm{~g} / \mathrm{l}$ at $0 \mathrm{~min}$, after $12 \mathrm{~h}$ fast

(Mean values for the no. of observations given in parentheses)

\begin{tabular}{|c|c|c|c|c|c|c|c|c|}
\hline $\begin{array}{l}\text { Interval } \\
\text { after } \\
\text { injection } \\
\text { (min) }\end{array}$ & $\begin{array}{c}\text { Blood } \\
\text { glucose (4) } \\
(\mathrm{mmol} / \mathrm{l})\end{array}$ & $\begin{array}{c}\text { Total } \\
\text { carbo- } \\
\text { hydrate } \\
\text { (4) }(\mathrm{mg} / \mathrm{l})\end{array}$ & $\begin{array}{c}\text { Glucose } \\
\text { (copper- } \\
\text { reduction } \\
\text { method) (2) } \\
(\mathrm{mmol} / \mathrm{l})\end{array}$ & $\begin{array}{l}\text { Insulin (4) } \\
(\mathrm{U} / \mathrm{ml})\end{array}$ & $\begin{array}{l}\text { HGH (4) } \\
(\mathrm{mg} / \mathrm{ml})\end{array}$ & $\begin{array}{l}\text { FFA (2) } \\
(\mathrm{mmol} / \mathrm{l})\end{array}$ & $\begin{array}{c}\text { Amylase (2) } \\
(\mathrm{U} / \mathrm{l})\end{array}$ & $\begin{array}{r}\text { Urea (2) } \\
(\mathrm{mmol} / \mathrm{l})\end{array}$ \\
\hline-60 & $3 \cdot 6$ & 1120 & $3 \cdot 3$ & $13 \cdot 8$ & 2.9 & - & 168 & 4.0 \\
\hline-30 & 3.6 & - & 3.4 & $10 \cdot 4$ & 4.1 & $\overline{-}$ & $\overrightarrow{1}$ & - \\
\hline 0 & $3 \cdot 3$ & 1010 & 3.4 & $8 \cdot 3$ & $2 \cdot 1$ & 703 & 142 & 4.0 \\
\hline+2 & 7.5 & 3250 & 8.7 & 10.5 & 1.4 & - & - & - \\
\hline+5 & $7 \cdot 7$ & 3460 & 6.8 & 11.4 & 1.7 & - & 177 & - \\
\hline 10 & $7 \cdot 4$ & 3160 & 6.5 & 12.7 & 1.5 & 912 & - & - \\
\hline 20 & 6.6 & 2630 & $6 \cdot 1$ & 12.3 & 3.5 & - & - & - \\
\hline 30 & 6.0 & 2130 & $5 \cdot 2$ & $8 \cdot 1$ & $3 \cdot 2$ & 820 & 125 & - \\
\hline 40 & 5.8 & 2100 & $5 \cdot 3$ & $8 \cdot 1$ & 2.8 & - & - & - \\
\hline 60 & $5 \cdot 2$ & 2070 & 4.9 & 11.2 & 1.9 & 946 & 123 & 3.8 \\
\hline 90 & 4.9 & 1800 & $4 \cdot 1$ & 12.3 & 1.6 & 799 & - & - \\
\hline 120 & 4.6 & 1640 & 4.3 & 11.4 & $2 \cdot 1$ & 876 & 116 & - \\
\hline 150 & 4.4 & 1490 & $4 \cdot 2$ & 11.5 & 2.4 & 885 & - & - \\
\hline 180 & $4 \cdot 4$ & 1810 & - & 10.5 & 2.4 & 848 & 115 & 3.8 \\
\hline
\end{tabular}

HGH 'human growth' hormone; FFA free fatty acids.

- For details of analytical procedures, see p. 342 .

Table 2. Renal excretion of dextrin* in four normal healthy subjects given $25 \mathrm{~g}$ Caloreen by rapid intravenous infusion, as a solution containing $300 \mathrm{~g} / \mathrm{l}$ at $0 \mathrm{~min}$ after $\mathrm{a} 12 \mathrm{~h}$ fast

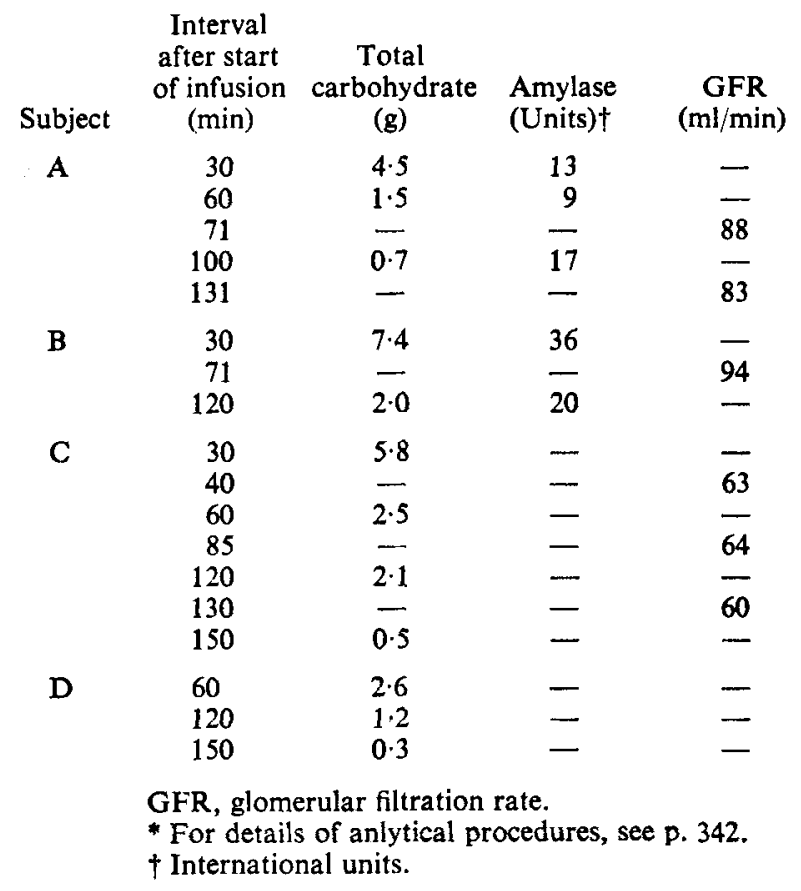




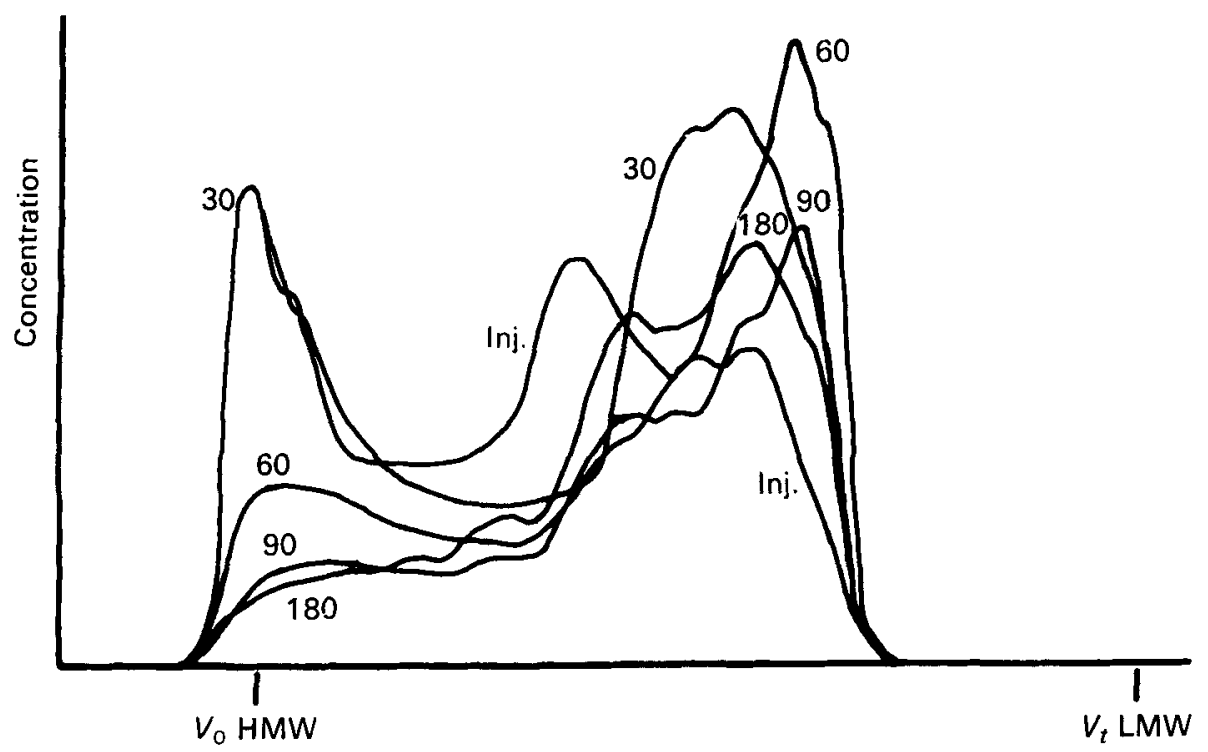

Fig. 1. Molecular size distribution on Sephadex G25 of injected dextrin (Caloreen) and dextrin present in successive urine samples from normal healthy subjects 30,60, 90 and 180 min after injection. Later samples contain a higher proportion of low-molecular-weight (LMW) dextrin molecules (Subject A). HMW, high molecular weight, $V_{0}$ void volume, $V_{t}$ total volume.

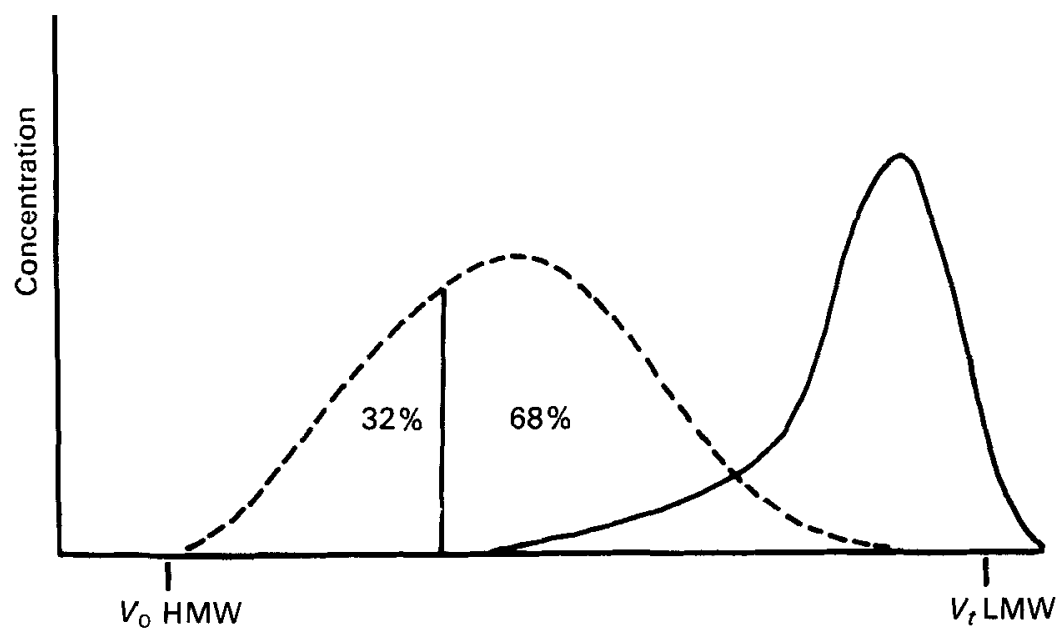

Fig. 2. Molecular size distribution on Sephadex G200 of Dextran $40(---)$ ) and dextrin (- - ) determined by gel filtration. The low-molecular-weight (LMW) component, $68 \%$ Dextran 40 was excreted through the kidney. All the molecules of dextrin are small enough to be excreted in this way. HMW, high molecular weight; $V_{0}$, void volume; $V_{t}$, total volume.

injection all subjects showed an appreciable loss of the dextrin in the urine; this varied from 4.04 to $10.81 \mathrm{~g}(16.2-43.2 \%$ of the dose).

Gel filtration, using Sephadex G-25, of the early urine samples taken after the injection of Caloreen showed a saccharide composition closely resembling that of the initial injection solution (Fig. 1). Successive urine samples showed an increasing proportion of smallermolecular-weight molecules, and glucose, maltose, tri-, tetra- and pentasaccharides were found. This was the reverse of the pattern found when dextran was infused; with the latter, 
Table 3. Results of analysis of blood and urine* from a normal healthy subject given $150 \mathrm{ml}$ Caloreen by intravenous infusion for $180 \mathrm{~min}$ as a solution containing $300 \mathrm{~g} / \mathrm{l}$

(Total dose infused $45 \mathrm{~g}$, loss in urine $30 \%$ of the dose)

$\begin{array}{cc}\begin{array}{c}\text { Interval } \\ \text { after start } \\ \text { of infusion } \\ \text { (min) }\end{array} & \begin{array}{c}\text { Sample } \\ \text { no. }\end{array} \\ -20 & 1 \\ 0 & 2 \\ 5 & 3 \\ 10 & 4 \\ 15 & 5 \\ 20 & 6 \\ 30 & 7 \\ 40 & 8 \\ 70 & 9 \\ 100 & 10 \\ 160 & 11 \\ 220 & 12 \\ 280 & 13 \\ 340 & 14 \\ 365 & 15\end{array}$

Blood glucose $(\mathrm{mmol} / \mathrm{l})$

\begin{tabular}{|c|c|c|c|c|c|}
\hline \multirow[b]{2}{*}{$\begin{array}{c}\text { Amylase } \\
\text { I.U.†/l }\end{array}$} & & \multirow{2}{*}{$\begin{array}{c}\text { Total } \\
\text { carbohydrate } \\
(\mathrm{mg} / \mathrm{l})\end{array}$} & \multirow[b]{2}{*}{$\begin{array}{l}\text { Insulin } \\
(\mathrm{U} / \mathrm{mi})\end{array}$} & \multirow[b]{2}{*}{$\begin{array}{c}\text { Urine } \\
\text { (g) }\end{array}$} \\
\hline & $\begin{array}{l}\text { Glucose } \\
\text { oxidase }\end{array}$ & $\begin{array}{l}\text { Copper } \\
\text { reduction }\end{array}$ & & & \\
\hline 165 & 5.4 & $5 \cdot 0$ & 770 & $10 \cdot 1$ & - \\
\hline - & 4.9 & $4 \cdot 9$ & 870 & 10.9 & - \\
\hline - & $5 \cdot 2$ & $5 \cdot 3$ & 1120 & $11 \cdot 3$ & - \\
\hline- & $6 \cdot 3$ & $5 \cdot 6$ & 1310 & 9.0 & - \\
\hline- & $6 \cdot 4$ & $5 \cdot 7$ & 1360 & $12 \cdot 6$ & - \\
\hline- & 6.6 & $5 \cdot 7$ & 1400 & $10 \cdot 6$ & - \\
\hline 155 & $6 \cdot 3$ & $5 \cdot 7$ & 1580 & 10.9 & - \\
\hline- & $7 \cdot 0$ & $6 \cdot 2$ & 1590 & 10.9 & - \\
\hline- & $7 \cdot 2$ & $6 \cdot 3$ & 1660 & 8.6 & 1.64 \\
\hline 88 & $8 \cdot 2$ & 6.8 & 2040 & $10 \cdot 5$ & 5.97 \\
\hline 72 & $8 \cdot 6$ & $6 \cdot 9$ & 2350 & 9.9 & - \\
\hline 52 & $7 \cdot 3$ & $6 \cdot 2$ & 1540 & $9 \cdot 7$ & 8.35 \\
\hline 70 & $6 \cdot 2$ & $5 \cdot 5$ & 1300 & $7 \cdot 9$ & - \\
\hline 58 & $5 \cdot 4$ & $5 \cdot 4$ & 1160 & $8 \cdot 0$ & - \\
\hline 52 & $5 \cdot 2$ & $5 \cdot 3$ & 1110 & $10 \cdot 9$ & - \\
\hline
\end{tabular}

* For details of analytical procedure, see p. 342. $\dagger$ International units.

the later urine samples tend to contain more of the larger-molecular-weight molecules. This evidence suggested that Caloreen was broken down in the body but did not exclude the possibility that there may have been some metabolism within the kidney itself. Gel filtration using Sephadex G-200 (Fig. 2) showed that all the molecules in Caloreen were capable of passage through the normal glomerulus. It was notable that the paper chromatography of urine from subject $\mathrm{C}$ showed that there was virtually no glucose, although maltose was detected.

Table 3 shows the result of infusing $150 \mathrm{ml}$ Caloreen $(300 \mathrm{~g} / \mathrm{l})$ during a $3 \mathrm{~h}$ period with continued biochemical monitoring for an additional $3 \mathrm{~h}$ in a fasting subject. There was no significant increase in insulin level either during the infusion, or in the next $3 \mathrm{~h}$.

In view of the lack of insulin response it was decided to investigate the response to an intravenous load of maltose, a disaccharide with two glucose molecules with a 1,4 linkage. Accordingly, two subjects were given $25 \mathrm{~g}$ maltose by intravenous injection, under similar experimental conditions to the Caloreen studies. Once again, despite the increase in glucose level in plasma, the level of insulin did not change, see Table 4 . In both subjects some $12-16 \%$ of the dose was excreted in the urine by $30 \mathrm{~min}$, but unfortunately it was not possible to study additional urine samples.

In a third study, it was decided to look at the effect of an infusion of Caloreen on the RQ in fasting subjects. Subjects were fasted for $16 \mathrm{~h}$ before the study, and the RQ was measured twice during the first 'resting' hour. At zero time, an infusion of Caloreen was begun, the cannula having been inserted earlier and saline infusion used to keep the needle patent. Infusion of Caloreen was done using an accurately-calibrated infusion pump (Braun) at a rate of $50 \mathrm{ml} / \mathrm{h}$. Blood glucose, total carbohydrate, plasma insulin and $R Q$ were measured at $30 \mathrm{~min}$ intervals throughout the $4 \mathrm{~h}$ of the study. There was a steadily progressive increase in blood glucose and total carbohydrate over the period of the study, but again there was no increase in the fasting level of insulin, as shown in Table 5. Serum lactate and free fatty acids were measured in several subjects but showed no significance change, 
Table 4. Results of the analyses of blood and urine* from two normal healthy subjects given $25 \mathrm{~g}$ maltose intravenously as solution containing $500 \mathrm{~g} / \mathrm{l}$ at $0 \mathrm{~min}$

(Mean values are given. Subjects excreted a mixture of maltose and glucose, $1 \cdot 6+2 \cdot 4$ and $2 \cdot 0+0.9$ respectively, in the first $30 \mathrm{~min}$ after injection)

$\begin{array}{cccc}\begin{array}{c}\text { Interval } \\ \text { after } \\ \text { injection } \\ \text { (min) }\end{array} & \begin{array}{c}\text { Blood } \\ \text { glucose } \\ (\mathrm{mmol} / \mathrm{l})\end{array} & \begin{array}{c}\text { Total } \\ \text { carbohydrate } \\ (\mathrm{mg} / \mathrm{l})\end{array} & \begin{array}{c}\text { Insulin } \\ (\mathrm{U} / \mathrm{ml})\end{array} \\ 0 & 3.6 & 630 & 18 \\ 2 & 6.4 & 2610 & 16 \\ 5 & 7 \cdot 8 & 3350 & 23 \\ 10 & 7.5 & 2910 & 19 \\ 15 & 7.0 & 2740 & 21 \\ 20 & 7 \cdot 0 & 2520 & 21 \\ 30 & 6.4 & 2360 & 20 \\ 40 & 6.4 & 2260 & 22 \\ 60 & 6.1 & 1690 & 20 \\ 90 & 4.8 & 1390 & 16 \\ 120 & 5.7 & 2190 & 19\end{array}$

* For details of analytical procedures, see p. 342.

thus providing no indirect evidence of the metabolism of the dextrin. The RQ remained steady during the early part of the studies but there was a small increase.

Studies of continuous infusion showed that although there was a progressive increase in blood glucose there was no stimulus to insulin release. Rates of infusion used were approximately $80 \mathrm{ml}$ Caloreen $(24 \mathrm{~g} / \mathrm{h})$ for $6 \mathrm{~h}$, and total plasma carbohydrate levels of $3460 \mathrm{mg} / \mathrm{l}$ (blood glucose levels of 7.77 and $8.33 \mathrm{mmol} / \mathrm{l}$ ) were reached (see for example Fig. 3). There was a progressive decrease in plasma amylase levels in all infusion experiments. Experiments showed that Caloreen added to serum in concentration up to $5 \mathrm{~g} / \mathrm{l}$ did not interfere with the determination of amylase by the 'dye' method. Total urinary excretion was $44-58 \%$ of the dose infused in these studies.

A further series of infusion studies using the lower rate of $50 \mathrm{ml}$ Caloreen for $3 \mathrm{~h}$ (total dose $45 \mathrm{~g}$ ) were undertaken with urine collection continuing for an additional $3 \mathrm{~h}$, when the excretion was almost complete (e.g. see Table 3). The urinary loss was 39 and $35 \%$ of the dose in the two subjects investigated, showing that urinary loss was dependent on the plasma concentration achieved. As all molecules in Caloreen are capable of filtration at the glomerulus the retention of between 40 and $65 \%$ of the dose suggests utilization and metabolism within the body.

To investigate the possibility that the lack of insulin response was due to the active suppression of insulin release, a third series of infusion tests was carried out in which an injection of $1 \mathrm{~g}$ tolbutamide BP was given intravenously $60 \mathrm{~min}$ after the start of the infusion of Caloreen, which was continued for another $2 \mathrm{~h}$ and monitored for another $5 \mathrm{~h}$. As shown in Fig. 4, insulin responses to tolbutamide were normal despite the lack of insulin response to the Caloreen; this was confirmed in a total of four subjects at the two centres of investigation. Likewise, the insulin response to an intravenous injection of glucose was normal in a subject receiving a continuous infusion of Caloreen (Fig. 5). The results of a similar experiment with glucagon are illustrated in Fig. 6 . These studies demonstrate that the responsiveness of the islet cells of the pancreas was preserved.

A substance intended for parenteral nutrition must be given in large amounts and clearly there are limits to what may be given to volunteers. After extensive tests in monkeys had shown no contraindication, three subjects received between 400 and $500 \mathrm{ml}$ Caloreen 


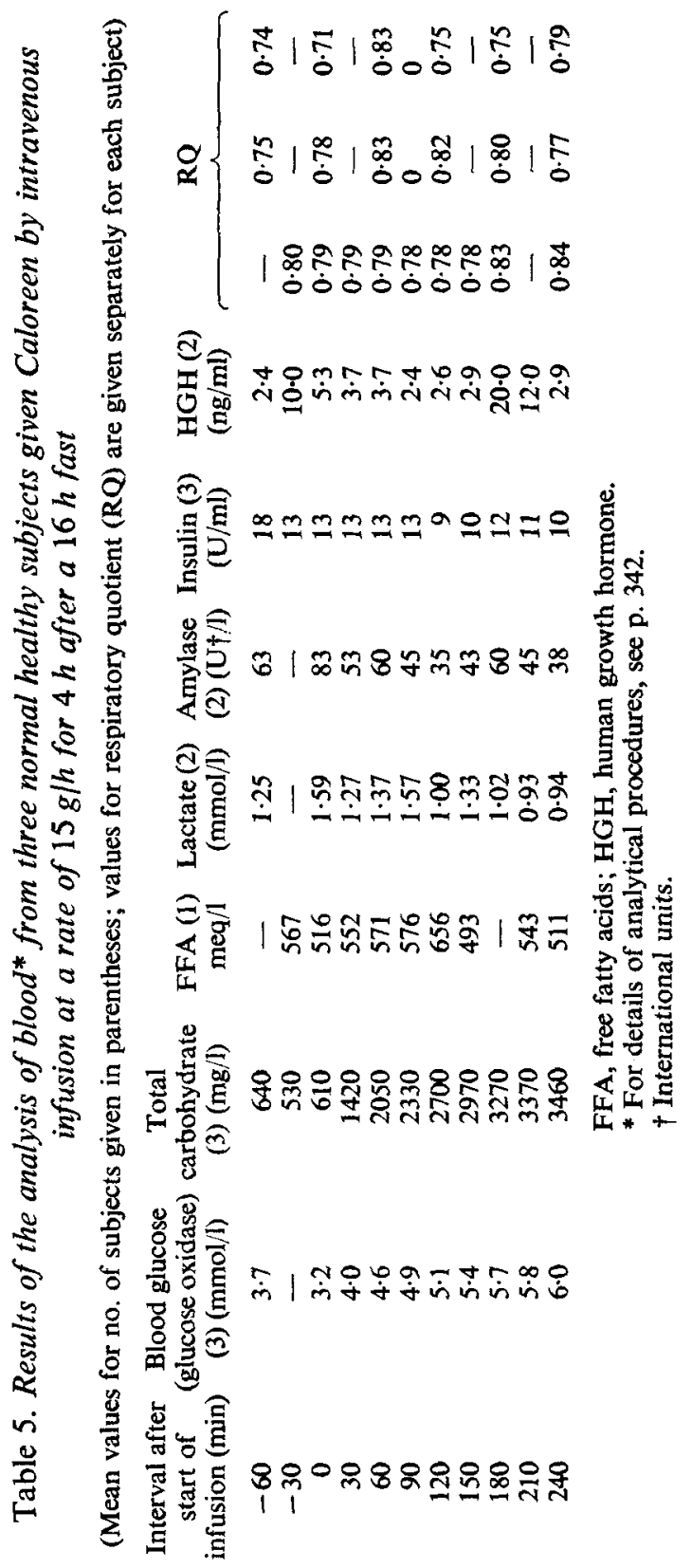




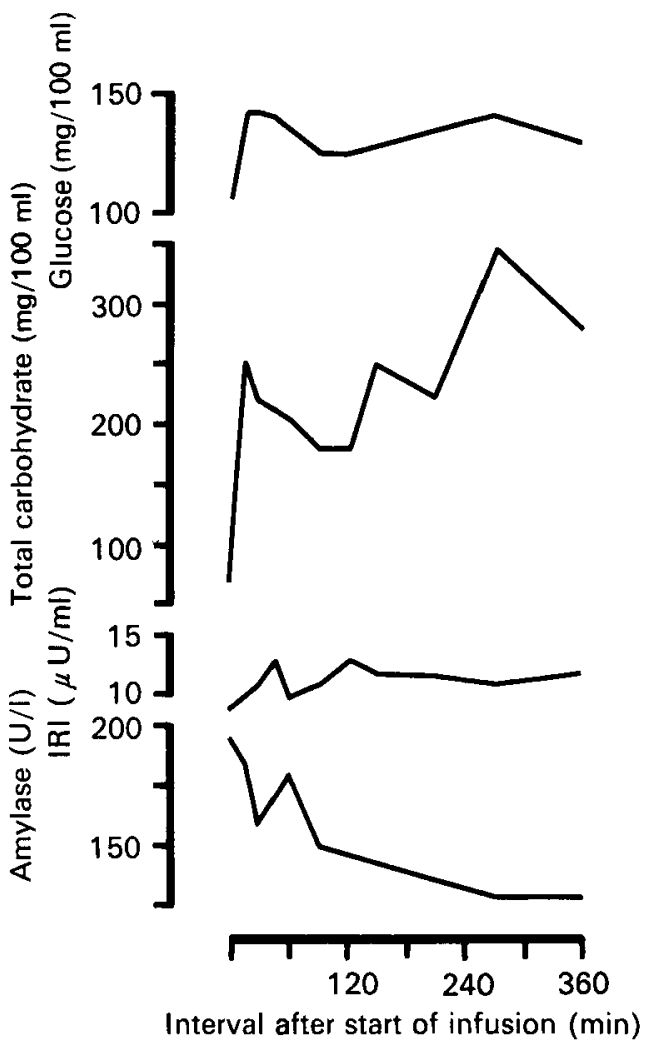

Fig. 3.

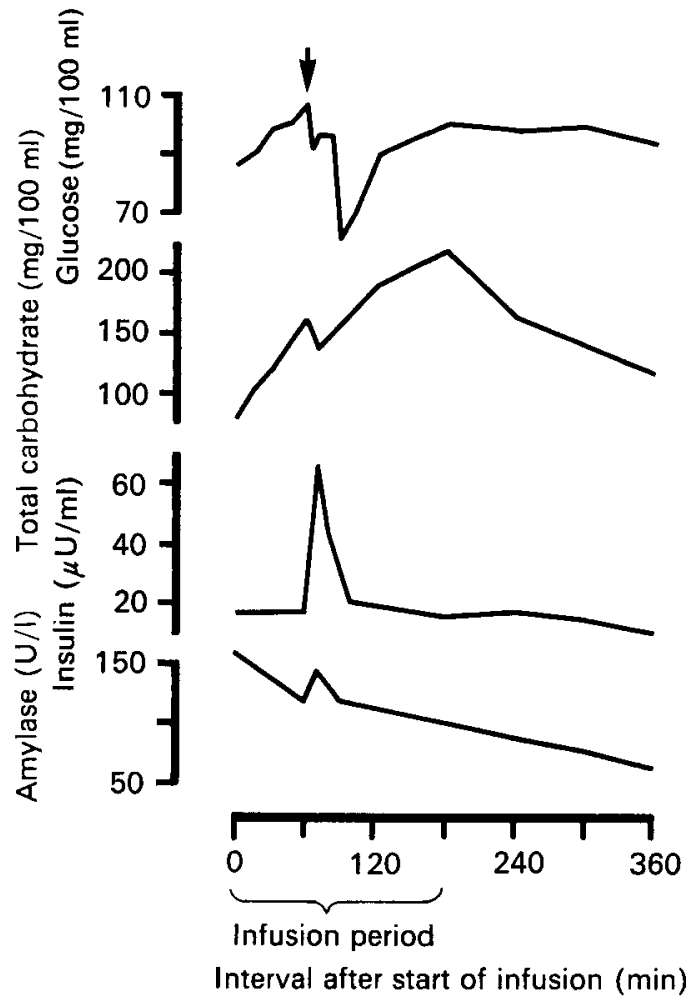

Fig. 4.

Fig. 3. Effect of continuous infusion of Caloreen $(25 \mathrm{~g} / \mathrm{h})$ for $4 \mathrm{~h}$ on total carbohydrate, blood glucose, immuno-reactive insulin (IRI) in the blood and plasma amylase activity in healthy subjects.

Fig. 4. Response of immuno-reactive insulin and plasma levels of total carbohydrate and amylase to injection of $1 \mathrm{~g}$ Tolbutamide given intravenously during continuous infusion of Caloreen $(15 \mathrm{~g} / \mathrm{h})$.

$(300 \mathrm{~g} / \mathrm{l})$, corresponding to $120-150 \mathrm{~g}$ by intravenous infusion in a $6 \mathrm{~h}$ period. Representative values from a single subject are shown in Table 6 .

Finally, a group of subjects was fasted for $15 \mathrm{~h}$ to study the change in the level of plasma amylase. Samples were taken after 9,12 and $15 \mathrm{~h}$ of fasting and no significant variation was found, which suggests that the change in amylase during the Caloreen infusion was not due to fasting, but was due directly to the metabolism of the Caloreen.

\section{DISCUSSION}

After a bolus injection of $25 \mathrm{~g}$ Caloreen, an increase in total carbohydrate was seen, followed in parallel by an increase in blood glucose, but this increase was not as marked. The reduction in total carbohydrate followed the same pattern as the decrease in blood glucose but was rather steeper, see Fig. 7. The extent of change was not of the same proportion as that seen in in vitro studies, and suggested some increase in 'true' glucose as confirmed by the $\mathrm{Cu}$-reduction studies. The stimulus to insulin secretion was not great, particularly as the sugar was given intravenously, and the insulin level did not become 


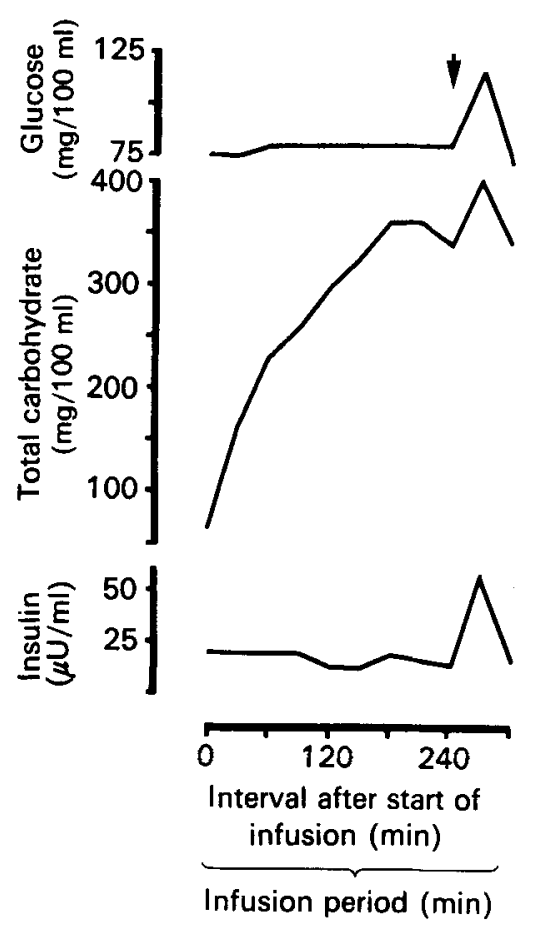

Fig. 5.

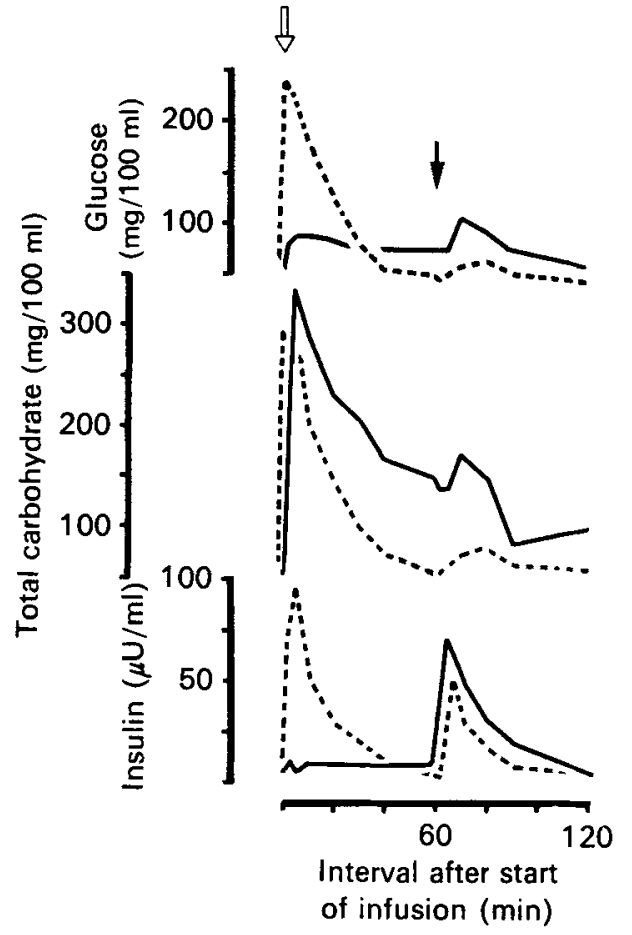

Fig. 6.

Fig. 5. Response of insulin to injection of $25 \mathrm{~g}$ glucose given intravenously during continuous infusion of Caloreen $(25 \mathrm{~g} / \mathrm{h})$ into normal healthy subjects.

Fig. 6. Response of insulin to injection of $1 \mathrm{mg}$ glucagon given intravenously $1 \mathrm{~h}$ after a single intravenous injection of $25 \mathrm{~g}$ Caloreen $(-)$ or glucose $(---)$ in healthy subjects.

higher than basal values, cf. Elrick, Stimmler, Head \& Ari (1964). The unexpected decrease in amylase after injection or infusion was less easy to explain. It may be that amylase and Caloreen form an insoluble complex which is taken up into cells of the reticulo-endothelial system.

Early urine samples contained dextrin with a similar distribution of molecular weight to the injected dextrin. Later samples, 2 or $3 \mathrm{~h}$ after injection, were found to contain a higher proportion of smaller-molecular-weight dextrin molecules. This was the reverse of the position after injection of dextrin when later samples contained a higher proportion of larger-molecular-weight molecules. This finding is an indication of the breakdown of dextrin through the action of the amylase.

The late response of the RQ to the infusion of Caloreen may simply have been a reflection of the slow rate of breakdown of Caloreen when given intravenously, too slow to produce the response in RQ normally seen after intravenous injection of glucose.

Prolonged infusion studies showed similar results to single-injection studies, with slower but similar changes in blood glucose and total carbohydrate, and a progressive decrease in amylase, which was not found on simple starvation. The fact that the failure of insulin response was not due to suppression of insulin release was shown by the ability of intravenous glucose, tolbutamide and glucagon to evoke a normal increase in 'immunoassayable' insulin within the first hour of infusion.

On the whole the evidence suggested that Caloreen given intravenously was slowly broken 
Table 6. Results of the analysis of blood* from a normal healthy subject given $500 \mathrm{ml}$ Caloreen by intravenous infusion for approximately $6 \mathrm{~h}$

(Total dose infused $150 \mathrm{~g}$; total urinary carbohydrate excretion in 413 mins was 65.46 g i.e. $44 \%$ of the total dose of Caloreen)

$\begin{array}{cccccc}\begin{array}{c}\text { Interval } \\ \text { after start } \\ \text { of infusion } \\ \text { (min) }\end{array} & \begin{array}{c}\text { Sample } \\ \text { no. }\end{array} & \begin{array}{c}\text { Glucose } \\ (\mathrm{mmol} / \mathrm{l})\end{array} & \begin{array}{c}\text { Total } \\ \text { carbohydrate } \\ (\mathrm{mg} / \mathrm{l})\end{array} & \begin{array}{c}\text { Amylase } \\ (\mathrm{U} \dagger / 1)\end{array} & \begin{array}{c}\text { Insulin } \\ (\mathrm{U} / \mathrm{ml})\end{array} \\ 0 & 1 & 5 \cdot 9 & 710 & 195 & 9 \cdot 2 \\ 2 \frac{1}{2} & 2 & - & - & 180 & 6 \cdot 3 \\ 8 & 3 & - & - & - & 15 \cdot 1 \\ 13 & 4 & - & - & - & 10 \cdot 8 \\ 18 & 5 & 7 \cdot 9 & 2470 & 185 & 9 \cdot 5 \\ 33 & 6 & 7 \cdot 9 & 2200 & 160 & 10 \cdot 6 \\ 48 & 7 & 7 \cdot 8 & - & - & 12.9 \\ 63 & 8 & 7 \cdot 4 & 2030 & 180 & 10 \cdot 2 \\ 108 & 9 & 6.9 & 1820 & 150 & 11 \cdot 2 \\ 123 & 10 & 6 \cdot 9 & 1790 & - & 12 \cdot 5 \\ 153 & 11 & 7 \cdot 2 & 2490 & - & 11 \cdot 8 \\ 188 & 12 & 7 \cdot 6 & 2650 & - & 13.9 \\ 233 & 13 & 7 \cdot 1 & 2250 & 130 & 11 \cdot 6 \\ 293 & 14 & 7 \cdot 8 & 3460 & 130 & 10 \cdot 6 \\ 353 & 15 & 7 \cdot 2 & 2790 & 130 & 12 \cdot 1 \\ 413 & 16 & - & 2070 & - & -\end{array}$

* For details of analytical procedures, see p. 342.

t International units.

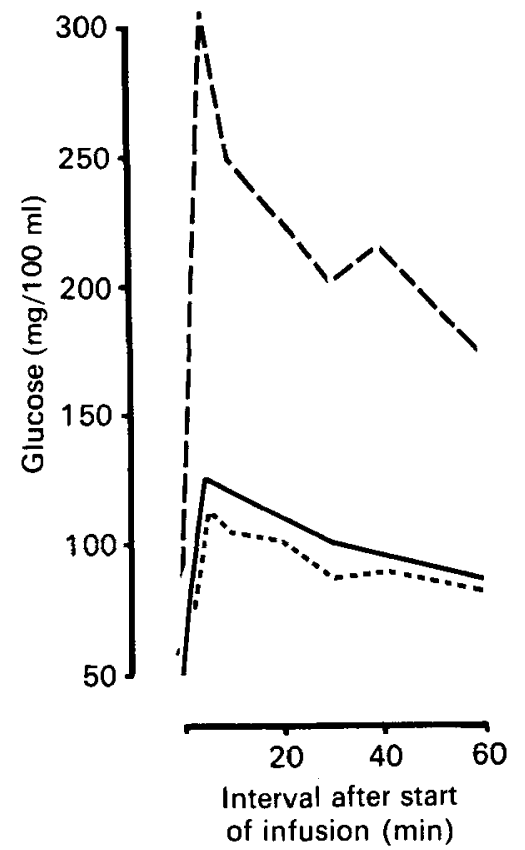

Fig. 7. Total carbohydrate estimated by the anthrone method (- - ), blood glucose estimated by glucose oxidase $(-)$ and by a copper reduction method $(---)$ in a normal subject given a single injection of $25 \mathrm{~g}$ Caloreen intravenously. 
down in the body, perhaps too slowly for it to be considered an efficient nutrient, particularly in view of its slow effect on RQ. 'Ordinary' food would be expected to yield a substantial portion of its nutriment within a few hours and it is questionable whether Caloreen given intravenously does this, though there is no doubt at all about its effectiveness when given orally.

Loss into the urine was fairly high as with other carbohydrate infusions but about half the infused dose was retained in the body and was available for metabolism. Between 15 and $45 \%$ of the infused dose was excreted in the urine. As would be expected, the larger the dose the larger the amount excreted. Because of the low molecular weight of the dextrin and correspondingly low viscosity of solutions, the urine was, in no instance, viscous. However, the high urinary loss is one of the main reasons why this dextrin is not suitable for parenteral nutrition.

Possibly a dextrin with fewer branch-links would be more quickly and completely converted to maltose and so be more efficiently metabolized. It looks as if conversion to maltose is the rate-determining step since maltose appears to be only slightly more slowly metabolized in man than glucose (Young \& Weser, 1971, 1974).

The absence of branch-links might enable the amylase to 'desorb' more quickly from the dextrin after 'splitting off' maltose, so minimizing the postulated loss of amylase-dextrin complex from the bloodstream with a consequent decrease in plasma amylase activity, which was found to occur in every subject investigated.

The authors thank the volunteers who made this work possible. The helpful cooperation of technical staff at Manchester Royal Infirmary and Whiston Hospital is gratefully acknowledged. Gel-filtration experiments and analysis for total carbohydrates were done by the late Mr Michael Hall of the MRC Industrial Injuries and Burns Unit.

\section{REFERENCES}

Berlyne, G. M., Booth, E. M., Brewis, R. A. L. \& Mallick, N. P. (1969). Lancet i, 689.

Bibby, R. J., Davies, D., Mallick, N. P., Atherton, S. T., Wright, D. M., Sherwood-Jones, E., Ricketts, C. R. \& Hall, M. (1974). Clin. Sci. 46, $7 P$.

Campbeil, E. J. M. (1960). Br. med. J. i, 457.

Clerbaux, Th., Gerets, G. \& Frans, A. (1973). J. Lub. clin. Med. 82, 342.

Elrick, H., Stimmler, L., Head, C. J. \& Ari, Y. (1964). J. Endocr. 24, 1076.

Hales, C. N. \& Randle, P. J. (1963). Biochem. J. 88, 137.

Hunter, W. M. \& Greenwood, F. C. (1964). Biochem. J. 91, 43.

Mallick, N. P., Davies, D. \& Dobbs, R. J. (1972). Uremia [R. Kluthe, G. Berlyn and B. Burton, editors]. London: Churchill-Livingstone.

Peaston, M. J. T. (1968). Hospital Medicine 1, 708.

Roe, J. H. (1954). J. biol. Chem. 208, 889.

Trinder, P. (1969). Ann. clin. Biochem. 6, 24.

Varley, H. (1969). Practical Clinical Biochemistry, 4th ed. p. 86. London: Heinemann.

Young, J. M. \& Weser, E. J. (1971). J. clin. Invest. 50, 986.

Young, J. M. \& Weser, E. J. (1974). J. clin. exp. Med. 38, 181. 